\title{
A simple one-pot multicomponent synthesis of an octahedral nanocontainer molecule
}

\author{
Xuejun Liu \& Ralf Warmuth \\ Department of Chemistry and Chemical Biology, Rutgers. The State University of New Jersey, 610 Taylor Road, Piscataway, New Jersey 08854, USA. Correspondence \\ should be addressed to R.W. (warmuth@rutgers.edu). \\ Published online 17 May 2007; doi:10.1038/nprot.2007.193 \\ A nearly quantitative 18-component synthesis of a nanocontainer, which is built up from six bowl-shaped cavitands that are connected \\ together with $12-\mathrm{CH}=\mathrm{N}-\mathrm{CH}_{2} \mathrm{CH}_{2}-\mathrm{N}=\mathrm{CH}$ - linkers, and its subsequent reduction are described. This nanocontainer has an estimated \\ cavity volume of $1,700 \AA^{3}$, large enough to encapsulate several smaller guest molecules or a small-sized biomacromolecule. Potential \\ uses of this nanocontainer and of water-soluble derivatives are in drug delivery, wastewater detoxification, separation technology \\ and as molecular reactor for controlled oligomerizations. Typically, the four-step synthesis of the cavitand building block and the \\ subsequent multicomponent synthesis of the nanocontainer, including its purification, can be accomplished in about 4 weeks.
}

\section{INTRODUCTION}

Molecular container compounds are hollow spherical hosts with cavities that allow accommodation of one or multiple guest molecules $^{1-3}$. They are of great interest as nanoreactors ${ }^{4,5}$, in which fleeting intermediates are stabilized $^{6-9}$, reactions accelerated $^{10,11}$ and regio- and stereochemistry altered ${ }^{12-14}$, as well as for solar energy conversion ${ }^{15}$, nanodevice fabrication ${ }^{16}$, drug delivery $^{17}$, storage and separation technology ${ }^{18}$. The discovery of self-assembly processes involving hydrogen bonding or metal coordination, in which multiple building blocks spontaneously assemble to form spherically and cylindrically shaped molecular capsules held together by hydrogen bonding or metal-ligand interactions, has tremendously increased the diversity of capsules with respect to shape and size ${ }^{19-23}$. The efficiency of such self-assembly approaches is best demonstrated in the quantitative multicomponent synthesis of structurally well-defined molecular spheres with cavity diameters that reach $5 \mathrm{~nm}$ (see refs. 24,25). The synthesis of similar-sized nanocapsules, in which building blocks are covalently linked, is especially desirable for biomedical applications. We recently reported a nearly quantitative one-pot 18-component synthesis of an octahedral nanocontainer that is built up from six bowl-shaped cavitands and 12 linker units held together by 24 newly formed imine bonds (Fig. 1) (ref. 26). Our approach strongly surpasses earlier multistep covalent synthesis of related nanocontainers in its simplicity and efficiency, which should facilitate applications in medicinal, analytical, chemical and material sciences ${ }^{27,28}$. Important was the choice of imine bonds to connect building blocks during the synthesis. Imine bond formation is reversible, which provides an error correction mechanism such that ultimately the thermodynamically most stable product-in this case 1 -is obtained ${ }^{29,30}$. A subsequent reduction of all 24 imine bonds fixes the structure and produces amino groups that allow further functionalization of the nanocapsule. From molecular mechanics calculations, a cavity volume of approximately $1,700 \AA^{3}$ was estimated for $\mathbf{1}$ and $\mathbf{4}$, which is sufficient for encapsulation of multiple small organic molecules or a small biomacromolecule. We see potential use of suitably functionalized or immobilized nanocapsules in drug delivery, wastewater detoxification, separation technology or as building blocks for new sensors.

The synthesis of $\mathbf{1}$ involves condensation of six tetraformylcavitands 2 with twelve 1,2-ethylene-diamines 3 in chloroform in the presence of catalytic amounts of trifluoroacetic acid (TFA). Cavitand 2 can be prepared in gram quantities in four steps from resorcinol and hexanal according to the literature procedures

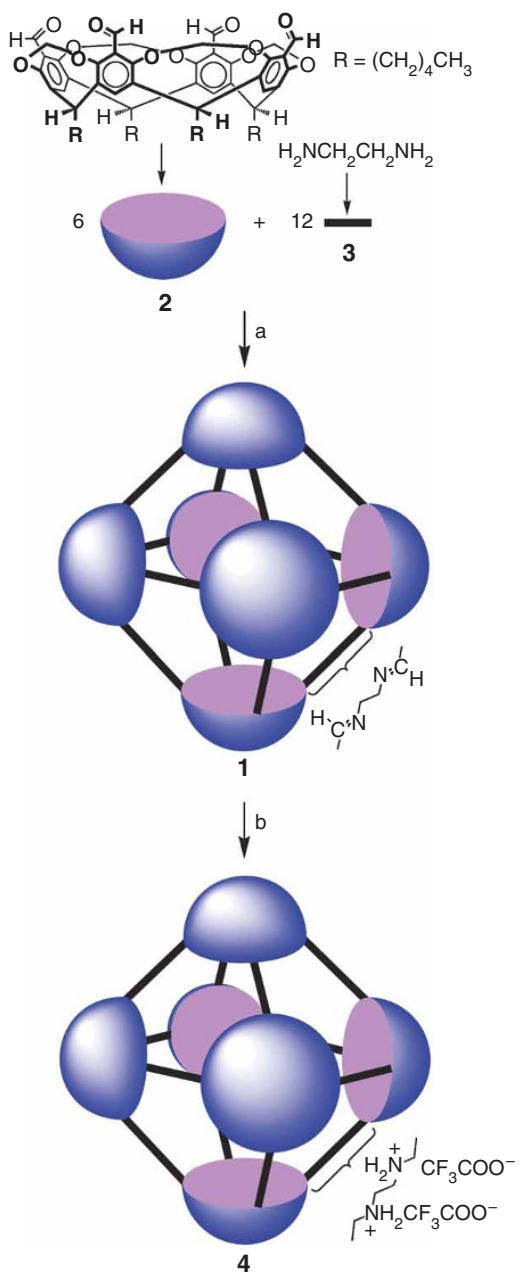

Figure 1 | 18-component synthesis of nanocontainer 1 and imine bond reduction. Conditions: (a) $\mathrm{CF}_{3} \mathrm{COOH}$ catalytic, $\mathrm{CHCl}_{3}$, room temperature; (b) 1. $\mathrm{NaBH}_{4}, \mathrm{CHCl}_{3} / \mathrm{CH}_{3} \mathrm{OH}$; 2. $\mathrm{HCl}$ conc. in $\mathrm{CH}_{3} \mathrm{OH}$; 3. $\mathrm{NaOH}$; 4. RP-HPLC $\mathrm{CH}_{3} \mathrm{OH} / \mathrm{H}_{2} \mathrm{O} / \mathrm{CF}_{3} \mathrm{COOH}$. 


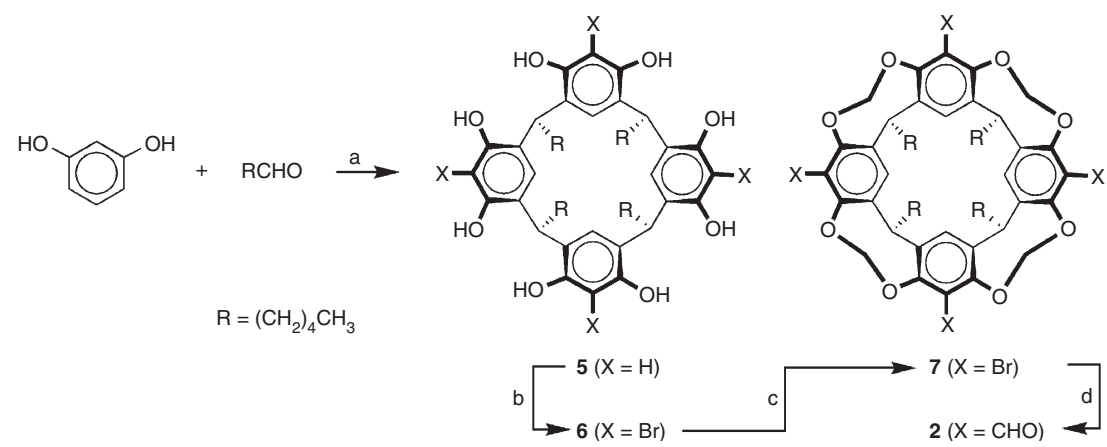

Figure 2 | Synthesis of cavitand 2 (refs. 31-34). Conditions: (a) EtOH- $\mathrm{H}_{2} \mathrm{O}$-conc. $\mathrm{HCl}, 60{ }^{\circ} \mathrm{C}$; (b) $\mathrm{N}$-bromosuccinimide, 2-butanone, room temperature; (c) $\mathrm{BrCH}_{2} \mathrm{Cl}_{2} \mathrm{~K}_{2} \mathrm{CO}_{3}, \mathrm{DMF}, 65^{\circ} \mathrm{C}$; (d) $1 . \mathrm{BuLi}, \mathrm{THF}$, $-78{ }^{\circ} \mathrm{C}$; 2. DMF, $-78{ }^{\circ} \mathrm{C} \rightarrow$ room temperature; $3.5 \% \mathrm{NH}_{4} \mathrm{Cl} \cdot(\mathrm{aq})$.

(Fig. 2) (see refs. 31-34 and Boxes 1-4). It is stable in the solid state but the formyl groups slowly oxidize in aerated solution, which substantially lowers the yield of its condensation reaction with 3 . Upon mixing $\mathbf{2}$ and $\mathbf{3}$, hexamer $\mathbf{1}$ forms slowly at room temperature $\left(22{ }^{\circ} \mathrm{C}\right)$. Equilibrium is reached after $2-3$ days. The reaction is best monitored by ${ }^{1} \mathrm{H}$ NMR spectroscopy (Fig. 3).

Spectra taken at an early stage of the reaction show substantial amounts of tetramer $\mathbf{8}$, which subsequently converts into $\mathbf{1}$ (Figs. $3 b$ and 4). After full equilibration, the hexamer to tetramer ratio is approximately 15:1 (Fig. 3c). We have carried out this reaction on a half-gram scale and do not find a decrease in the yield of $\mathbf{1}$ as long as the reactants are of high purity. On the other hand, the condensation reaction is remarkably solvent dependent ${ }^{35}$. In solvents other than chloroform, the yield of $\mathbf{1}$ is considerably lower and other nanocages form preferentially. For example, in tetrahydrofuran (THF), tetramer $\mathbf{8}$ is the major condensation product and octamer 9 in dichloromethane (Fig. 4). For a discussion of the solvent effect on the outcome of the condensation reaction between 2 and 3 , the reader is referred to ref. 35 .

The reduction of all imine bonds of $\mathbf{1}$ with $\mathrm{NaBH}_{4}$ is quantitative and leads initially to boramines $-\mathrm{CH}_{2} \mathrm{~N}\left(\mathrm{BH}_{2}\right)$-, which have to be hydrolyzed under acidic conditions. Hydrolysis is slow and should be carried out at room temperature. We observe substantial acetal cleavage if hydrolysis is carried out at elevated temperature. An intramolecular acid catalysis by the ammonium groups might contribute to this side reaction (Fig. 5) (ref. 35).

Support for this cleavage mechanism comes from the observation of substantial acetal cleavage, if solid $\mathbf{4} \cdot 24 \mathrm{CF}_{3} \mathrm{CO}_{2} \mathrm{H}$ is heated to $80{ }^{\circ} \mathrm{C}$ under vacuum for $24 \mathrm{~h}$. At room temperature, side reactions are minimized and $4 \cdot 24 \mathrm{CF}_{3} \mathrm{CO}_{2} \mathrm{H}$ is obtained in $50-65 \%$ yield after purification by reversed-phase high-pressure liquid chromatography (HPLC). Nanocontainer $\mathbf{4} \cdot 24 \mathrm{HCl}$ is soluble in methanol:water 9:1, but precipitates if the water content is increased.

\section{MATERIALS}

\section{REAGENTS}

- Resorcinol (Fisher Scientific, cat. no. R254-500)

- Hexanal (Sigma-Aldrich, cat. no. 115606)

- $N$-bromosuccinimide (Fisher Scientific, cat. no. B81255)

- Bromochloromethane (Sigma-Aldrich, cat. no. 135267)

- Anhydrous $\mathrm{K}_{2} \mathrm{CO}_{3}$ (Fisher Scientific, cat. no. P208-500)

-1,2-Ethylenediamine (3) (Sigma-Aldrich, cat. no. 391085)

- Trifluoroacetic acid (Acros Organics, cat. no. 293812500)

- Chloroform-d (Sigma-Aldrich, cat. no. 151823)

- Sodium borohydride $\left(\mathrm{NaBH}_{4}\right.$; Sigma-Aldrich, cat. no. 452882)

- 4 A molecular sieves, 8-12 meshes (Acros Organics, cat. no. 197250050)

$\cdot \mathrm{NH}_{4} \mathrm{Cl}$

- Hydrochloric acid (minimum 37\% w/w)

- Ethanol (95\%)

- Methyl ethyl ketone (Sigma-Aldrich, cat. no. 360473)

- Acetone

- Methanol

- Dichloromethane

- Ethylacetate

- Sodium hydroxide

- Anhydrous $\mathrm{MgSO}_{4}$

- Sea sand

- Flash silica gel (Sorbent Technology, cat. no. 10930-25)

- Aluminum backing silica gel thin-layer chromatography (TLC) plates with

fluorescence indicator (Sorbent Technology, cat. no. 1634126)

- HPLC solvent A: $0.1 \%$ TFA in methanol

- HPLC solvent B: $0.1 \%$ TFA in distilled water

EQUIPMENT

- Three-necked round-bottomed flasks, 250, 1,000 and 2,000 ml

- Round-bottomed flask, $250 \mathrm{ml}$

- Reflux condenser

- Addition funnel, $250 \mathrm{ml}$

- Mechanical stirrer assembly
- Thermometer, -10 to $110{ }^{\circ} \mathrm{C}$

- Low-temperature thermometer, -90 to $40{ }^{\circ} \mathrm{C}$

- Teflon-coated magnetic stir bars

- Heating mantle for 2,000 $\mathrm{ml}$ round-bottomed flasks

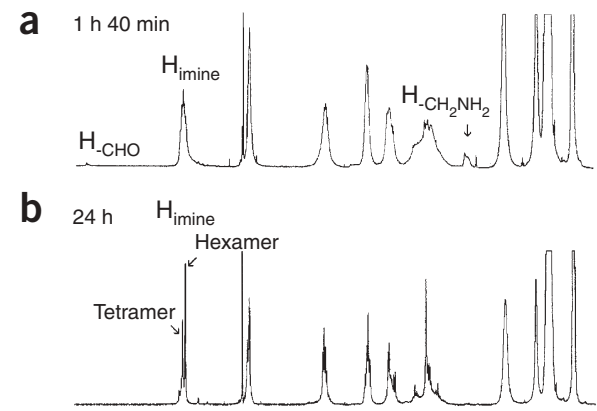

C $69 \mathrm{~h} \quad \mathrm{H}_{\text {imine }}$
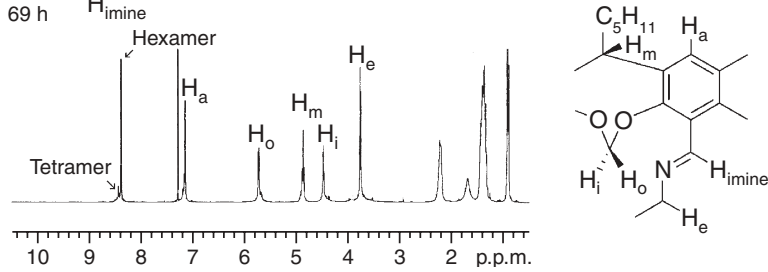

Figure $3 \mid{ }^{1} \mathrm{H}-\mathrm{NMR}$ spectra $\left(25^{\circ} \mathrm{C}, \mathrm{CDCl}_{3}\right.$, a and $\left.\mathbf{c}, 400 \mathrm{MHz}, \mathbf{b}, 300 \mathrm{MHz}\right)$ of products formed upon mixing 2 with two equivalents of 3 in $\mathrm{CHCl}_{3}$ containing catalytic amounts of $\mathrm{CF}_{3} \mathrm{CO}_{2} \mathrm{H}$ after $100 \mathrm{~min}(\mathrm{a}), 24 \mathrm{~h}(\mathbf{b})$ and $69 \mathrm{~h}(\mathbf{c})$. Imine proton resonances of hexamer $\mathbf{1}$ and tetramer $\mathbf{8}$ are marked with arrows. 


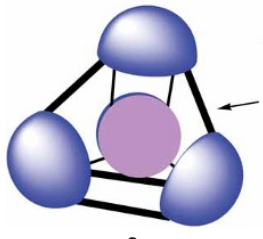

8

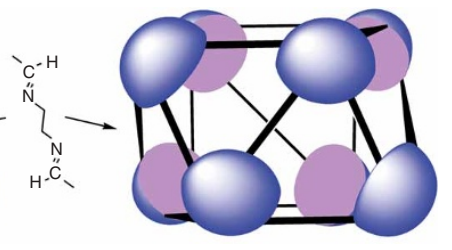

9
Figure 4 | Tetrameric (8) and octameric (9) nanocapsules.

- Rotavaporator (Buchi, Model R-3000); vacuum pump (Buchi, Model V-500); vacuum controller (Buchi, Model V-800)

-Vacuum pump (Fisher Scientific, Maximal C plus, model M2C)

- HPLC with UV detector: dual pump solvent delivery, Varian prostar 210;

UV-visible detector, Varian prostar 345

-HPLC column: Vydac, protein and peptide C18, $5 \mu \mathrm{m}, 300 \AA$ А, $4.6 \times 250$

$\mathrm{mm}$, cat. no. 218TP54; Vydac, protein and peptide C18, $10 \mu \mathrm{m}, 300 \AA$,

$22 \times 250 \mathrm{~mm}$, cat. no. $218 \mathrm{TP} 1022$

-HPLC syringe: Hamilton Microliter 750 syringe, $500 \mu \mathrm{l}$, 710 syringe, $100 \mu \mathrm{l}$

- Glass-threaded vials (Fisher Scientific, $1.8 \mathrm{ml}$, cat. no. 03-339-21A; $11.1 \mathrm{ml}$, cat. no. 03-339-21E)

- Three-port Schlenck line

- Chromatography column with a $250 \mathrm{ml}$ reservoir, $2.56 \mathrm{~cm}$ i.d. $\times 30.72 \mathrm{~cm}$ length

\section{REAGENT SETUP}

Chloroform Chloroform (Sigma-Aldrich, cat. no. 319988) may contain substantial amounts of $\mathrm{HCl}$, which catalyzes the slow decomposition of nanocage 1. It should be freshly purified by filtration through a pad of $\mathrm{Na}_{2} \mathrm{CO}_{3}$ before use.
THF Dry and deoxygenate THF (Fisher Scientific, cat. no. T425-4) either with a solvent purification system (e.g., SolvTek) by passing it under nitrogen through an activated alumina column and a column containing a copper oxygen scrubber or by distilling it under nitrogen from sodium with sodium benzophenone ketyl as an indicator.

$\mathrm{N}, \mathrm{N}$-dimethylformamide Evacuate $\mathrm{N}, \mathrm{N}$-dimethylformamide (DMF, SigmaAldrich, cat. no. 494488) for $5 \mathrm{~min}$ at $0.1-1 \mathrm{~mm} \mathrm{Hg}$, in order to remove trace amounts of amines. Vent with nitrogen or argon and store over activated molecular sieves $(4 \AA$ ) under argon or nitrogen.

$n$-Butyl lithium $n$-Butyl lithium (BuLi, $2.5 \mathrm{M}$ solution in hexanes; SigmaAldrich, cat. no. 230707) slowly decomposes at room temperature. Even though an excess of BuLi is used, the concentration of BuLi should be determined as described in detail in refs. 36,37, if the BuLi solution has been stored for a longer time at room temperature.

EQUIPMENT SETUP

HPLC Set up a preparative HPLC method with a flow rate of $15 \mathrm{ml} \mathrm{min}^{-1}$ and UV-visible detection at $\lambda=280 \mathrm{~nm}$.

\begin{tabular}{ll}
\hline Time (min) & \% B \\
\hline System equilibration $(20-30 \mathrm{~min})$ & 15 \\
$0-15$ & $15-2$ \\
$15-25$ & 2 \\
$25-27$ & $2-15$
\end{tabular}

Flash column chromatography Pack a chromatography column with $\sim 150$ $\mathrm{ml}$ of suspended silica gel in dichloromethane $\left(\mathrm{CH}_{2} \mathrm{Cl}_{2}\right)$. Cover the top of the silica gel with a $0.5 \mathrm{~cm}$ layer of sand.

TLC Fill TLC tank with 95:5 (v/v) $\mathrm{CH}_{2} \mathrm{Cl}_{2} / \mathrm{EtOAc}$.

\section{PROCEDURE}

1| Dry a $250 \mathrm{ml}$ three-necked round-bottomed flask containing a Teflon-coated magnetic stir bar in an oven (at least $1 \mathrm{~h}$ ). Remove the flask from the oven and connect it to a Schlenck line. Evacuate hot flask and allow it to cool to room temperature under vacuum. Vent flask with argon and keep it under argon during the following steps (Steps 2-10).

2| Weigh out $65.3 \mathrm{mg}(72.6 \mu \mathrm{l} ; 1.09 \mathrm{mmol})$ ethylenediamine (3) into a $1.8 \mathrm{ml}$ vial. Add $1.0 \mathrm{ml}$ chloroform into the vial and close the cap.

$\triangle$ CRITICAL STEP Ethylenediamine is added in a $2.8 \mathrm{~mol} \%$ excess relative to the tetraformyl cavitand (2), as the condensation reaction is accelerated by the presence of trace amounts of ethylenediamine. It should be of high purity in order to obtain a high yield. Ethylenediamine can react with carbon dioxide and be oxidized in air. Therefore, exposure to air should be minimized.

3| Place $490 \mathrm{mg}(0.528 \mathrm{mmol})$ tetraformyl cavitand (2) into an $11.1 \mathrm{ml}$ vial. Add $2.0 \mathrm{ml}$ chloroform and sonicate for $1 \mathrm{~min}$.

4| Transfer the solution into the reaction flask using a $500 \mu \mathrm{l}$ glass syringe. Rinse the vial four times with $0.5 \mathrm{ml}$ chloroform each. Add additional $30.0 \mathrm{ml}$ chloroform into the reaction flask.

$\triangle$ CRITICAL STEP In solution, the formyl groups of 2 are easily oxidized by dissolved oxygen. As the yield of the condensation step also depends on the purity of the tetraformyl cavitand, exposure to air should be minimized and the reaction flask should be kept under positive argon pressure.

5| Transfer the ethylenediamine solution into the reaction flask using a $500 \mu \mathrm{l}$ glass syringe. Rinse the vial six times with $0.5 \mathrm{ml}$ each of chloroform. Add additional $3.0 \mathrm{ml}$ chloroform into the reaction flask so that the total volume of chloroform is $41.0 \mathrm{ml}$.

6| While under argon, sonicate the solution for 2 min by immersing it in an ultrasound bath. This removes any dissolved oxygen, which will be exchanged for argon.

7| Add $3.9 \mu \mathrm{l}(0.053 \mathrm{mmol})$ TFA into the reaction flask. This initiates the condensation reaction. The solution may turn pale yellow as the reaction proceeds. The color is due to the

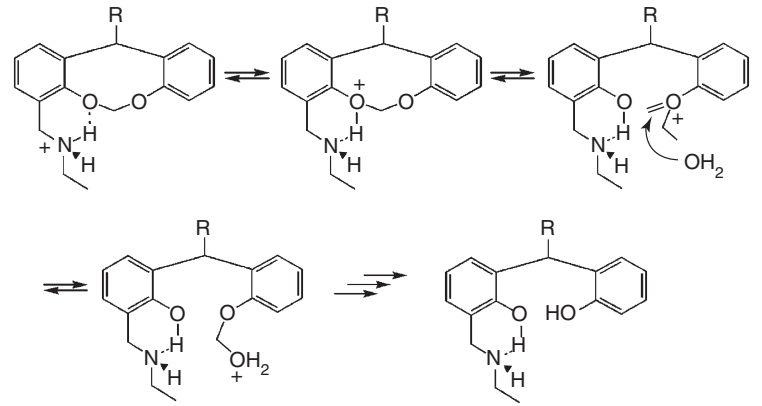

Figure 5 | Proposed intramolecular acid-catalyzed acetal hydrolysis of 4. Reproduced with permission from J. Am. Chem. Soc. 128, 14120-14127 (2006). Copyright 2006 American Chemical Society. 
formation of trace amounts of side products. However, this does not affect the reaction.

I CAUTION TFA is highly corrosive. If a Hamilton microliter syringe or an Eppendorf pipetter is used for the addition of the TFA, the syringe should be rinsed immediately with plenty of water and any TFA vapor inside the Eppendorf pipetter should be removed by passing a stream of air through the pipetter body.

8| Check the stoichiometry $30 \mathrm{~min}$ after TFA addition. Take out a $0.2 \mathrm{ml}$ aliquot of the reaction solution and place it into a $10 \mathrm{ml}$ round-bottomed flask. Remove solvent at rotavaporator at room temperature and remove residual solvent using a high vacuum line (room temperature, $10 \mathrm{~min}$ ).

9| Dissolve the residue in $0.7 \mathrm{ml}$ chloroform- $d$ and record ${ }^{1} \mathrm{H}$ NMR spectrum. Add more ethylenediamine if residual aldehyde signal is observed ( $\delta=10.31$ p.p.m.). Add more tetraformyl cavitand if residual ethylenediamine signal is more than $3 \%$ $(\delta=3.0-2.7$ p.p.m.) (see Fig. 6$)$. Check the stoichiometry again 30 min later, if more reagent was added.

$\triangle$ CRITICAL STEP The yield of the condensation step is highest if the stoichiometry between ethylenediamine and tetraformyl cavitand is 2:1.

10| Continue stirring for an additional $41 \mathrm{~h}$ at room temperature under argon.

PAUSE POINT Can be left for $41 \mathrm{~h}$ at room temperature.

$\triangle$ CRITICAL STEP We usually check the progress of the reaction by ${ }^{1} \mathrm{H}$ NMR spectroscopy as described in Steps 8 and 9 before proceeding to the reduction step (Step 11). If the integral of the nanocage imine signal (see Fig. 3c) is smaller than $60 \%$ of the total imine integral, the reaction time should be increased by $24 \mathrm{~h}$, after which another ${ }^{1} \mathrm{H}$ NMR spectrum should be recorded.

? TROUBLESHOOTING

11| Stir the reaction mixture vigorously (500-600 r.p.m.). Add $3.8 \mathrm{~g} \mathrm{NaBH} 4$ and stir for $3 \mathrm{~min}$.

! CAUTION $\mathrm{NaBH}_{4}$ is toxic and highly flammable.

? TROUBLESHOOTING

12| Add $0.4 \mathrm{ml}$ dry methanol (dried with $3 \AA$ molecular sieves for at least $24 \mathrm{~h}$ ) into the reaction flask and stir for $5 \mathrm{~min}$. Add an additional $3.7 \mathrm{ml}$ dry methanol. Continue stirring overnight at room temperature.

\section{BOX 1 | PREPARATION OF RESORCIN [4]ARENE 5}

Resorcin[4] arene 5 is prepared as described in ref. 31.

1. Place a 2,000 $\mathrm{ml}$ three-necked round-bottomed flask in a heating mantle. Equip the reaction flask with a $250 \mathrm{ml}$ addition funnel and a mechanical stirrer. Flush the flask with argon for $30 \mathrm{~min}$.

2. Add $104 \mathrm{~g}(0.94 \mathrm{~mol})$ resorcinol into the reaction flask. Add $470 \mathrm{ml}$ water, $470 \mathrm{ml}$ of $95 \%$ ethanol and $235 \mathrm{ml}$ conc. $\mathrm{HCl}$ into the reaction flask. Stir the reaction mixture until homogeneous solution. Equip the reaction flask with a thermometer.

3. Charge the additional funnel with $114 \mathrm{ml}(95 \mathrm{~g}, 0.94 \mathrm{~mol})$ hexanal. Add hexanal into the reaction flask dropwise over $1 \mathrm{~h}$ while stirring the reaction mixture vigorously. During the addition, product might start precipitating.

4. Remove the addition funnel and equip the reaction flask with a cold water condenser and turn on the cold water. Turn on the heating mantle and raise the temperature of the reaction mixture to $60{ }^{\circ} \mathrm{C}$. Stir the reaction mixture at $60{ }^{\circ} \mathrm{C}$ for 3 days.

5. Turn off the heating mantle and remove it. Allow the reaction mixture to cool to room temperature. Remove the cold water condenser, the thermometer and the mechanical stirrer.

6. Filter off the precipitated product through a 2,000 ml medium porosity $(10-16 \mu \mathrm{m})$ sintered glass filter funnel. Use the mother liquid to rinse the reaction flask and transfer all the solids into the filter funnel. Wash the crude product with distilled water until the filtrate is neutral (check the filtrate with $\mathrm{pH}$ paper). Air-dry the residue overnight.

7. Transfer the residue into a $1,000 \mathrm{ml}$ round-bottomed flask and dry the crude product at a high vacuum line at $110{ }^{\circ} \mathrm{C}$ for $24 \mathrm{~h}$. The crude product is used for the next step (Box 2) without further purification (typical yield $80-90 \%$ ). For spectroscopic data of pure 5 , see ref. 31 .

TIMING

Steps 1-3: 2 h; Step 4: 3 days; Steps 5 and 6: 8 h; Step 7: 1 day. 


\section{BOX 2 | PREPARATION OF TETRABROMORESORCIN [4]ARENE 6}

Tetrabromoresorcin[4]arene 6 is prepared as described in ref. 32.

1. Place a 2,000 $\mathrm{ml}$ three-necked round-bottomed flask into a cooler ice bucket. Equip the reaction flask with a mechanical stirrer and a thermometer. Flush the flask with argon for 30 min.

2. Add $833 \mathrm{ml}$ methyl ethyl ketone into the reaction flask. Add $87 \mathrm{~g}(0.11 \mathrm{~mol})$ of resorcin[4]arene 5 into the reaction flask. Stir the reaction mixture until homogeneous solution.

3. Add ice into the ice bucket and cool the reaction solution to below $10^{\circ} \mathrm{C}$.

4. Turn off light in the hood and wrap the reaction flask with an aluminum foil. Add $120 \mathrm{~g}(0.67 \mathrm{~mol})$ NBS into the reaction flask in small portions so that the temperature of the reaction mixture stays below $10^{\circ} \mathrm{C}$.

$\triangle$ CRITICAL STEP NBS is photo- and thermosensitive. Furthermore, the reaction is exothermic and the temperature may rise too quickly if the addition is too rapid. Therefore, the reaction should be conducted in the dark and the temperature of the reaction mixture should be kept below $10{ }^{\circ} \mathrm{C}$ during the NBS addition.

! CAUTION NBS partially brominates the solvent. These brominated by-products are strong lachrymators. Therefore, the reaction, the workup and the cleaning of the equipment should be carried out in a well-ventilated fume hood.

5. Remove the ice bucket and allow the reaction mixture to warm up to room temperature. Stir the reaction mixture for $24 \mathrm{~h}$ at room temperature.

6. Remove the aluminum foil, the thermometer and the mechanical stirrer.

7. Pour the reaction mixture containing the precipitated product onto a $600 \mathrm{ml}$ fine-porosity (4.0-5.5 $\mu \mathrm{m})$ sintered glass filter funnel. Use the mother liquid to rinse the reaction flask and transfer the remaining solid into the filter funnel. Wash the solid five times with $100 \mathrm{ml}$ precooled acetone $\left(-20^{\circ} \mathrm{C}\right)$. Wash the solid five times with $200 \mathrm{ml}$ distilled water each. Wash the solid with additional $100 \mathrm{ml}$ precooled acetone. Air-dry the crude product overnight.

$\triangle$ CRITICAL STEP The product slightly dissolves in acetone. Product losses may occur if the product is washed with non-cooled acetone.

8. Transfer the product (white powder, typical yield $70-90 \%$ ) into a $100 \mathrm{ml}$ round-bottomed flask and dry it at a high vacuum line at $110^{\circ} \mathrm{C}$ for $24 \mathrm{~h}$. The product is pure enough to be used without further purification for the next step (Box 3). For spectroscopic data of pure 6, see ref. 32. - TIMING

Steps 1-4: 2 h; Step 5: 1 day; Steps 6 and 7: 8 h; Step 8: 1 day.

$\triangle$ CRITICAL STEP The equilibrium of the condensation reaction can be affected by water present in methanol and methanol itself. Water shifts the equilibrium toward the starting materials. Too much methanol also lowers the yield.

PAUSE POINT Can be left overnight at room temperature. ? TROUBLESHOOTING

13| Remove the solvent at the rotavaporator. Add $150 \mathrm{ml}$ water into the flask and sonicate for $10 \mathrm{~min}$.

\section{BOX 3 | PREPARATION OF TETRABROMO CAVITAND 7}

Tetrabromo cavitand $\mathbf{7}$ is prepared as described in ref. 32.

1. Place a $1,000 \mathrm{ml}$ three-necked round-bottomed flask in a heating mantle. Add $400 \mathrm{DMF} \mathrm{ml}$ into the reaction flask. Connect one neck of the flask to a high vacuum line and degas the solvent by applying vacuum for 5 min.

2. Vent with argon and keep the DMF under argon while equipping the flask with a mechanical stirrer and a thermometer.

3. Add $26.5 \mathrm{~g}(24.4 \mathrm{mmol})$ tetrabromoresorcin[4]arene 6 into the reaction flask. Stir the reaction mixture until all of 6 is dissolved. Add $54.3 \mathrm{~g}$ (390 mmol) $\mathrm{K}_{2} \mathrm{CO}_{3}$ into the reaction flask. Stir the reaction mixture for $2 \mathrm{~min}$.

4. Add the first portion of $6.6 \mathrm{ml}(102 \mathrm{mmol})$ bromochloromethane $\left(\mathrm{BrCH}_{2} \mathrm{Cl}\right)$ into the reaction flask while stirring the reaction mixture vigorously. ! CAUTION $\mathrm{BrCH}_{2} \mathrm{Cl}$ is volatile and highly toxic. It should be handled only in a well-ventilated fume hood.

5. Equip the reaction flask with a cold water condenser and turn on the cold water. Turn on the heating mantle and raise the temperature of the reaction mixture to $40^{\circ} \mathrm{C}$. Keep stirring the reaction mixture at $40{ }^{\circ} \mathrm{C}$ for $24 \mathrm{~h}$ under argon.

6. Add the second portion of $6.6 \mathrm{ml} \mathrm{BrCH}{ }_{2} \mathrm{Cl}$ into the reaction flask. Raise the temperature of the reaction mixture to $65^{\circ} \mathrm{C}$. Keep stirring the reaction mixture at $65^{\circ} \mathrm{C}$ for $24 \mathrm{~h}$.

7. Add the third portion of $6.6 \mathrm{ml} \mathrm{BrCH}{ }_{2} \mathrm{Cl}$ into the reaction flask. Continue stirring the reaction mixture at $65{ }^{\circ} \mathrm{C}$ for additional $24 \mathrm{~h}$.

8. Add the fourth portion of $6.6 \mathrm{ml} \mathrm{BrCH}{ }_{2} \mathrm{Cl}$ into the reaction flask and continue stirring the reaction mixture at $65^{\circ} \mathrm{C}$ for an additional $24 \mathrm{~h}$.

9. Turn off the mechanical stirrer and heating mantle. Remove the heating mantle. Allow the reaction mixture to cool to room temperature and leave the reaction mixture at room temperature for an additional $48 \mathrm{~h}$ without stirring.

- PAUSE POINT Can be left at room temperature for $48 \mathrm{~h}$.

10. Filter off the product and inorganic salts through a $600 \mathrm{ml}$ fine-porosity $(4.0-5.5 \mu \mathrm{m})$ sintered glass filter funnel. Wash the precipitate twice with $45 \mathrm{ml}$ DMF followed by three washes with $200 \mathrm{ml}$ distilled water each to remove inorganic salts. Wash the residue twice with $45 \mathrm{ml}$ methanol each. Air-dry the product overnight.

11. Transfer the residue into a $100 \mathrm{ml}$ round-bottomed flask and dry the product at a high vacuum line at $110^{\circ} \mathrm{C}$ for $24 \mathrm{~h}$. The product (off-white powder; typical yield 80-95\%) can be used without further purification for the next step (Box 4). For spectroscopic data of the pure product, see ref. 32.

- TIMING

Steps 1-3: 1 h; Steps 4-8: 4 days; Step 9: 2 days; Step 10: 8 h; Step 11: 1 day. 


\section{BOX 4 | PREPARATION OF TETRAFORMYL CAVTTAND 2}

Tetraformyl cavitand 2 is prepared as described in refs. 33,34 .

1. Transfer $5.0 \mathrm{~g}$ ( $4.42 \mathrm{mmol})$ tetrabromo cavitand 7 into a $500 \mathrm{ml}$ three-necked round-bottomed flask containing a Teflon-coated magnetic stir bar. Dry the starting material at high vacuum at $110^{\circ} \mathrm{C}$ overnight in order to remove traces of moisture and methanol.

$\triangle$ CRITICAL STEP The starting material should be fully dried before use since the reaction is moisture-sensitive.

2. Allow the flask to cool to room temperature under vacuum. Turn off vacuum and vent the flask with argon. While under argon, equip the flask with a low-temperature thermometer and a rubber septum.

$\triangle$ CRITICAL STEP Moisture should be prevented from entering the reaction flask. Therefore, the reaction flask should always be under positive argon pressure.

3. Add $250 \mathrm{ml}$ dry THF into the reaction flask. Stir the reaction mixture until $\mathbf{7}$ is completely dissolved.

$\triangle$ CRITICAL STEP THF should be fully dried before use.

4. Cool the reaction mixture to $-78^{\circ} \mathrm{C}$ by placing the flask into an acetone/dry ice cooling bath. It might be necessary to slightly increase the argon flow during the cooling of the reaction mixture.

5. Using a syringe, add $14.1 \mathrm{ml}(35.4 \mathrm{mmol}) n$-BuLi (2.5 $\mathrm{M}$ in hexanes) into the reaction flask. Stir the reaction mixture at $-78{ }^{\circ} \mathrm{C}$ for $20 \mathrm{~min}$. $\triangle$ CRITICAL STEP The yield of the reaction depends on the quality of $n$-BuLi.

6. Remove the acetone/dry ice bath and replace it with an ice/water cooling bath. Allow the temperature of the reaction mixture to rise to $0{ }^{\circ} \mathrm{C}$. Stir the reaction solution at $0{ }^{\circ} \mathrm{C}$ for $30 \mathrm{~min}$.

7. Replace the water/ice bath with an acetone/dry ice bath and $\operatorname{cool}$ the reaction solution to $-78{ }^{\circ} \mathrm{C}$. Stir the reaction mixture at $-78{ }^{\circ} \mathrm{C}$ for 5 min. Increase the argon flow during the cooling, if necessary.

8. Add using a syringe, $13.7 \mathrm{ml}(177 \mathrm{mmol})$ dry DMF into the reaction flask. Stir the reaction mixture at $-78^{\circ} \mathrm{C}$ for $10 \mathrm{~min}$. Remove the cooling bath and allow the reaction mixture to warm up to room temperature. Stir the reaction mixture at room temperature for an additional $1 \mathrm{~h}$. $\triangle$ CRITICAL STEP DMF should be fully dried before use.

9. Pour $100 \mathrm{ml}$ of $5 \% \mathrm{NH}_{4} \mathrm{Cl}(\mathrm{aq})$ into the reaction flask and stir for $10 \mathrm{~min}$.

10. Transfer the reaction mixture into a $1,000 \mathrm{ml}$ separation funnel. Extract the mixture with $200 \mathrm{ml}$ ethyl acetate (Et0Ac). Separate layers. Extract the aqueous layer twice with $100 \mathrm{ml}$ EtOAc each. Combine the organic layers. Wash them with $100 \mathrm{ml}$ of saturated $\mathrm{NaHCO}_{3}(\mathrm{aq})$ and subsequently with $100 \mathrm{ml}$ of brine (saturated $\mathrm{NaCl}(\mathrm{aq})$ ). Dry the organic layer over $\mathrm{MgSO}_{4}$ for $5 \mathrm{~min}$. Filter the mixture through a $60 \mathrm{ml}$ medium-porosity $(10-16 \mu \mathrm{m})$ sintered glass filter funnel. Rinse the residue three times with $5 \mathrm{ml}$ Et0Ac each. Remove solvent at the rotavaporator. Dry the residue under high vacuum at room temperature for $1 \mathrm{~h}$.

11. Purify the crude product by silica flash column chromatography. Dissolve the crude product $(1.0 \mathrm{~g})$ in a minimal volume of $\mathrm{CH}_{2} \mathrm{Cl}_{2}(1-2 \mathrm{ml})$ in a glass vial. Load the solution onto the silica column. Rinse the vial three times with $0.5 \mathrm{ml} \mathrm{CH}_{2} \mathrm{Cl}_{2}$ each. Elute the column under slightly positive air pressure with 95:5 (vol/vol) $\mathrm{CH}_{2} \mathrm{Cl}_{2} /$ EtOAc. Collect $20 \mathrm{ml}$ fractions using test tubes (18 mm i.d. $\times 150 \mathrm{~mm}$ length). Check fractions by TLC (silica gel; $95: 5$ ( vol/vol) $\mathrm{CH}_{2} \mathrm{Cl}_{2} /$ EtOAC). Visualize the developed TLC plates with a UV lamp at $\lambda=254 \mathrm{~nm}$. Identify fractions containing pure tetraformyl cavitand 2, which has $R_{\mathrm{f}}=0.15$. Combine fractions containing pure $\mathbf{2}$ and remove the solvent at the rotavaporator. Dry the white solid at high vacuum at room temperature for $1 \mathrm{~h}$. The typical yield of 2 is 60-70\%. For analytical data of pure 2, see ref. 34 .

$\triangle$ CRITICAL STEP In solution, the formyl groups of 2 are easily oxidized by dissolved oxygen. 0xidation is even faster during the silica column chromatography. Therefore, the contact time between the product and the silica gel should be kept as short as possible. Collected fractions should be combined and concentrated as soon as the chromatography is finished.

TIMING

Step 1: 8 h; Steps 2-6: 2 h; Steps 7 and 8: 1.5 h; Step 9: 15 min; Step 10: 3 h; Step 11: 3 h.

14| Filter off the crude boramine mixture through a medium-porosity (10-16 $\mu \mathrm{m})$ sintered glass filter funnel. Wash the white solid three times with $10 \mathrm{ml}$ water each and air-dry it for $10 \mathrm{~min}$.

$\triangle$ CRITICAL STEP Before proceeding to Step 15, the completion of the reduction should be checked by ${ }^{1} \mathrm{H}$ NMR spectroscopy in $\mathrm{CDCl}_{3}$. The absence of imine protons at $\delta=8.4 \pm 0.2$ indicates complete reduction. Otherwise, add $40 \mathrm{ml}$ chloroform and repeat Steps 11 and 12.

15| Prepare a solution composed of $150 \mathrm{ml}$ methanol and $15 \mathrm{ml}$ concentrated hydrochloric acid.

16| Transfer the crude boramine into a $250 \mathrm{ml}$ round-bottomed flask containing a stirring bar. Rinse the funnel with $10 \mathrm{ml}$ $\mathrm{MeOH} / \mathrm{HCl}$ solution and transfer the rinse solution into the flask. Pour the leftover $\mathrm{MeOH} / \mathrm{HCl}$ solution into the flask.

17| Continue stirring for an additional 3.5 days at room temperature. Check the progress of the hydrolysis using ESI MS or MALDI-TOF MS. This is carried out by neutralizing a small sample $(0.2-0.5 \mathrm{ml})$ with $1 \mathrm{M} \mathrm{NaOH} \mathrm{(aq)} \mathrm{and} \mathrm{extracting} \mathrm{it} \mathrm{into} \mathrm{dichloro-}$ methane before sample preparation for MS in order to remove chloride ions.

$\triangle$ CRITICAL STEP The product yield depends critically on the reaction time and is usually highest after about 3.5 days. If the reaction time is too short, the hydrolysis of $\mathrm{B}-\mathrm{N}$ bond is incomplete. $\mathrm{On}$ the other hand, if the reaction time is too long, a noticeable number of the acetal groups $\left(-\mathrm{OCH}_{2} \mathrm{O}-\right)$ are cleaved.

18| Dissolve $7.5 \mathrm{~g}(187.5 \mathrm{mmol}) \mathrm{NaOH}$ in $10 \mathrm{ml}$ water. Cool the solution to room temperature. Slowly add the solution into the reaction flask until the reaction mixture is slightly basic. Check pH of the solution with $\mathrm{pH}$ paper. 
19| Remove methanol at the rotavaporator at room temperature.

$\triangle$ CRITICAL STEP Connect a high-vacuum pump to the rotavaporator in order to remove methanol at room temperature. Amine is sensitive to oxidation. Minimize contact with air to reduce oxidation.

20| Filter the mixture through a fine-porosity $(4.0-5.5 \mu \mathrm{m})$ sintered glass filter funnel. Wash the white residue with enough water to remove all inorganic salts. Air-dry the residue for $30 \mathrm{~min}$.

21| Transfer the residue into a $25 \mathrm{ml}$ round-bottomed flask and dry it at high vacuum line at room temperature overnight. The crude product is a fine powder and may have a slight yellow color.

PAUSE POINT The product can be stored in freezer at $-20{ }^{\circ} \mathrm{C}$.

22| Dissolve $100 \mathrm{mg}$ crude product in $500 \mu \mathrm{l}$ methanol containing $30 \mu \mathrm{l} \mathrm{TFA}$. Suck the solution into a $1 \mathrm{ml}$ plastic syringe and pass it through a plastic syringe filter $(0.20-0.45 \mu \mathrm{m})$.

23 Inject the solution onto a preparative reversed-phased HPLC column at a flow rate of $15 \mathrm{ml} \mathrm{min}{ }^{-1}$. Monitor fractions by UV-visible at $\lambda=280 \mathrm{~nm}$.

24| Collect fractions containing the major product (retention time $t_{R} \sim 13.6 \mathrm{~min}$ ). Evaporate the solvent to obtain a white crystalline powder. It might be necessary to repurify overlapping fractions containing 4 24TFA and the by-product M-C (Figs. 7 and 8). a

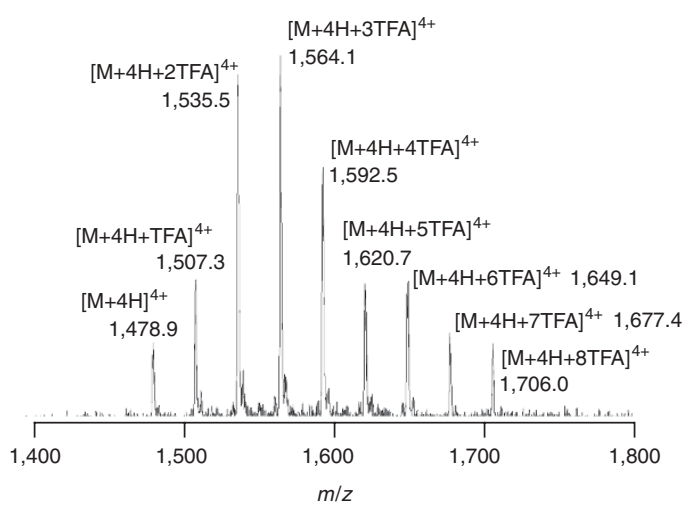

b

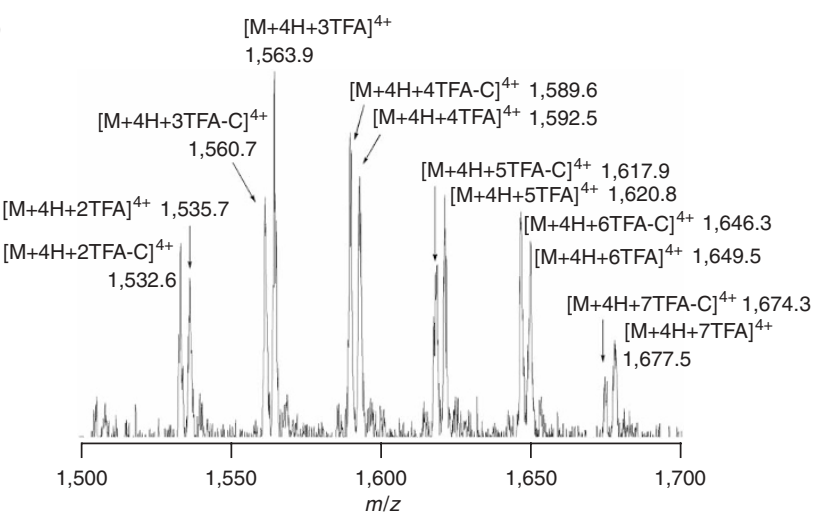

Figure 7 | ESI MS spectra of fractions collected from HPLC purification $\left(\mathrm{CH}_{3} \mathrm{OH} / \mathrm{H}_{2} \mathrm{O} / \mathrm{TFA}\right.$ 98:2:0.1). (a) Pure hexamer 4; (b) hexamer 4 plus nanocontainer lacking one acetal group.

25| Purify the remaining crude product in $100 \mathrm{mg}$ portions by repeating Steps 22-24.

\section{TIMING}

Step 1: $1.5 \mathrm{~h}$

Steps 2-7: $1 \mathrm{~h}$

Steps 8 and 9: $1 \mathrm{~h}$

Step 10: $41 \mathrm{~h}$

Steps 11 and 12: $8 \mathrm{~h}$

Steps 13 and 14: $1 \mathrm{~h}$

Steps 15 and 16: $0.5 \mathrm{~h}$

Step 17: 3.5 days

Steps 18-21: $1.5 \mathrm{~h}$

Steps 22-25: $8 \mathrm{~h}$

? TROUBLESHOOTING

Troubleshooting advice can be found in Table 1 .

TABLE 1 | Troubleshooting table.

\begin{tabular}{lll}
\hline Problem & Possible reason & Solution \\
\hline Low yield of the condensation step & $\begin{array}{l}\text { Tetraformyl cavitand or ethylenediamine is } \\
\text { of poor quality }\end{array}$ & $\begin{array}{l}\text { Purify tetraformyl cavitand by normal-phase } \mathrm{HPLC} \\
\text { using } 2.3 \text { vol\% } \mathrm{THF}_{\mathrm{CH}} \mathrm{Cl}_{2} \text { as mobile phase }\end{array}$ \\
$\begin{array}{ll}\text { Stoichiometry deviates too much from the } \\
\text { correct ratio }(\mathbf{2 : 3}=1: 2)\end{array}$ & $\begin{array}{l}\text { Distill ethylenediamine under argon at atmospheric } \\
\text { pressure. Check the stoichiometry by }{ }^{1} \mathrm{H} \text { NMR and } \\
\text { adjust it accordingly (see Fig. } \mathbf{6})\end{array}$ \\
& $\begin{array}{l}\text { Oxygen intervention during reaction } \\
\text { Chloroform contains } \mathrm{HCl}\end{array}$ & $\begin{array}{l}\text { Make sure the reaction is protected under argon } \\
\text { Freshly filter } \mathrm{CHCl}_{3} \text { through a pad of } \mathrm{Na}_{2} \mathrm{CO}_{3}\end{array}$ \\
\hline
\end{tabular}


TABLE 1 | Troubleshooting table (continued).

\begin{tabular}{lll}
\hline Problem & Possible reasons & Solution \\
\hline Rate of condensation too slow & TFA is of poor quality; ethylenediamine is & Use fresh TFA. Add 2.8 mol\% excess ethylenedia- \\
not in slight excess, but an excess of formyl & mine \\
groups is present &
\end{tabular}

Rate of the reduction step too slow

The reduced product does not completely dissolve in $\mathrm{CH}_{3} \mathrm{OH} / \mathrm{HCl}$ solution

Signals for products with partially cleaved acetal observed in the mass spectrum of the hydrolysis mixture or of the crude product
Hydrolysis time is too long; the crude product has been heated during workup
Use fresh $\mathrm{NaBH}_{4} \cdot \mathrm{NaBH}_{4}$ is hydroscopic and should be kept in a desiccator

Add more $\mathrm{CH}_{3} \mathrm{OH} /$ conc. $\mathrm{HCl}$ (10:1) solution to ensure clear solution. In any event, do not heat the solution

Reduce the reaction time. Avoid heating the hydrolysis reaction mixture or the crude product

\section{ANTICIPATED RESULTS Typical yields}

The typical yield of the condensation step is approximately $75 \%$ as determined by integration of the imine proton signal of 1 at $\delta=8.34$ relative to the total integration of the imine proton signals in the ${ }^{1} \mathrm{H}$ NMR spectrum of crude 1 (Fig. $3 \mathrm{c}$ ). The yield also depends on the reaction stoichiometry and is highest if $\mathbf{2}$ and $\mathbf{3}$ are added in an exact 1:2 ratio (82\%). However, under these conditions, the reaction rate is slowest, as excess amino groups catalyze the transimination steps needed to reach equilibrium. An excellent compromise between yield and rate is the use of a small excess of amine (maximal $3 \%$, which always gives greater than $70 \%$ yield. The subsequent reduction of $\mathbf{1}$ is essentially quantitative. The hydrolysis of the resulting boramine requires careful attention. The correct length of the hydrolysis step is very critical. If it is too short or too long, the presence of unhydrolyzed B-N groups or partially cleaved $\mathrm{OCH}_{2} \mathrm{O}$ acetal groups will strongly reduce the yield of 4 and make its purification more difficult. The exact time of the completion of this step is best determined by MALDI-TOF or ESI mass spectrometry. The ESI mass spectrum of $\mathbf{4}$ is shown in Figure 7. Each unhydrolyzed B-N bond increases the mass of the hexameric nanocage by approximately 12 mass units and each cleaved acetal reduces the mass by 12 (see Fig. $7 \mathbf{b}$ ). After complete hydrolysis, a small fraction of the acetal groups (typically less than 1\%) will be cleaved. Fortunately, these by-products can be separated from 4 by HPLC. A representative HPLC profile of the crude product 4 24TFA is shown in Figure 8. The product peak partially overlaps with that of a nanocontainer lacking one acetal (M-C). ESI-mass spectra of the purified product $\mathbf{4}$ and that of an overlapping fraction containing $\mathbf{4}$ and the nanocontainer lacking one acetal $(\mathrm{M}-\mathrm{C})$ are shown in Figure $\mathbf{7 a , b}$. After HPLC, the typical isolated yield of the final product 4 is $60 \%$ based on the starting material tetraformyl cavitand 2 .

\section{Analytical data}

Condensation product 1: ${ }^{1} \mathrm{H}$ NMR $\left(400 \mathrm{MHz}, \mathrm{CDCl}_{3}, 22{ }^{\circ} \mathrm{C}\right) \delta 8.34(\mathrm{~s}, 24 \mathrm{H}, \mathrm{CHN}) ; 7.12\left(\mathrm{~s}, 24 \mathrm{H}, \mathrm{H}_{\text {ary }}\right) ; 5.70(\mathrm{~d}, \mathrm{~J}=7.5 \mathrm{~Hz}, 24 \mathrm{H}$, $\left.0 \mathrm{CH}_{\text {out }} \mathrm{HO}\right) ; 4.83\left(\mathrm{t}, \mathrm{J}=8 \mathrm{~Hz}, 24 \mathrm{H}, \mathrm{CH}\left(\mathrm{CH}_{2}\right)_{4} \mathrm{CH}_{3}\right) ; 4.46\left(\mathrm{~d}, \mathrm{~J}=7.5 \mathrm{~Hz}, 24 \mathrm{H}, 0 \mathrm{CH}_{\text {in }} \mathrm{HO}\right) ; 3.75(\mathrm{sb}, 48 \mathrm{H}, \mathrm{NCH} 2) ; 2.25-2.15$ (m, 48H, $\left.\mathrm{CHCH}_{2}\left(\mathrm{CH}_{2}\right)_{3} \mathrm{CH}_{3}\right) ; 1.5-1.3\left(\mathrm{~m}, 144 \mathrm{H}, \mathrm{CHCH}_{2}\left(\mathrm{CH}_{2}\right)_{3} \mathrm{CH}_{3}\right) ; 0.91\left(\mathrm{t}, \mathrm{J}=7.1 \mathrm{~Hz}, 72 \mathrm{H} ; \mathrm{CHCH}_{2}\left(\mathrm{CH}_{2}\right)_{3} \mathrm{CH}_{3}\right)$.

${ }^{13} \mathrm{C}$ NMR $\left(100 \mathrm{MHz}, \mathrm{CDCl}_{3}, 22{ }^{\circ} \mathrm{C}\right.$; $) \delta 157.7,153.6,138.8,124.5,121.7,100.5,63.2,36.7,32.3,30.1,27.9,23.0,14.4$. FT-IR $\left(\mathrm{CHCl}_{3}\right) \vee 2,956.8(\mathrm{~s}), 2,929.6(\mathrm{~s}), 2,872.1(\mathrm{sh}), 2,855.6$

(s) $1,641.5(\mathrm{~s}), 1,602.6(\mathrm{~m}), 1,587(\mathrm{~m}), 1,361.3(\mathrm{~m}), 1,112.3$

(w), 1,088.9 (m), $980(\mathrm{~s})$.

ESI-MS $\left(\mathrm{CH}_{2} \mathrm{Cl}_{2} / \mathrm{CH}_{3} \mathrm{CN}(1: 5)(\mathrm{m} / z)\right.$ 1,954.9 $(100 \%$, $\left.[\mathrm{M}+3 \mathrm{H}]^{3+}\right) ; 1,466.9\left(13 \%,[\mathrm{M}+4 \mathrm{H}]^{4+}\right) ; 1,173.7\left(3 \%,[\mathrm{M}+5 \mathrm{H}]^{5+}\right)$.

Final product 4: ${ }^{1 \mathrm{H}} \mathrm{NMR}\left(\mathrm{CD}_{3} \mathrm{OD} ; 0.4\right.$ vol\% $\mathrm{CF}_{3} \mathrm{COOD} ; 7{ }^{\circ} \mathrm{C}$; $300 \mathrm{MHz}) \delta 7.55\left(\mathrm{~s}, 24 \mathrm{H}, \mathrm{H}_{\mathrm{aryl}}\right) ; 6.16(\mathrm{~d}, \mathrm{~J}=6.9 \mathrm{~Hz}, 24 \mathrm{H}$, $\left.\mathrm{OCH}_{\text {out }} \mathrm{HO}\right) ; 4.85\left(\mathrm{t}, \mathrm{J}=7.6 \mathrm{~Hz}, 24 \mathrm{H}, \mathrm{CH}\left(\mathrm{CH}_{2}\right)_{4} \mathrm{CH}_{3}\right) ; 4.43(\mathrm{~d}$, $\left.\mathrm{J}=6.9 \mathrm{~Hz}, 24 \mathrm{H}, \mathrm{OCH}_{\text {in }} \mathrm{HO}\right) ; 4.16\left(\mathrm{sb}, 48 \mathrm{H}, \mathrm{NCH}_{2} \mathrm{Ar}\right) ; 3.59$ (sb, $\left.48 \mathrm{H}, \mathrm{N}\left(\mathrm{CH}_{2}\right)_{2} \mathrm{~N}\right) ; 2.38\left(\mathrm{sb}, 48 \mathrm{H}, \mathrm{CHCH}_{2}\left(\mathrm{CH}_{2}\right)_{3} \mathrm{CH}_{3}\right) ; 1.6-1.2$ $\left(\mathrm{m}, 144 \mathrm{H}, \mathrm{CHCH}_{2}\left(\mathrm{CH}_{2}\right)_{3} \mathrm{CH}_{3}\right) ; 0.92(\mathrm{t}, \mathrm{J}=7.1 \mathrm{~Hz}, 72 \mathrm{H}$; $\left.\mathrm{CHCH}_{2}\left(\mathrm{CH}_{2}\right)_{3} \mathrm{CH}_{3}\right)$.

${ }^{13} \mathrm{C}$ NMR $\left(\mathrm{CD}_{3} \mathrm{OD} ; 0.4\right.$ vol\% $\left.\mathrm{CF}_{3} \mathrm{COOD} ; 22{ }^{\circ} \mathrm{C} ; 75 \mathrm{MHz}\right) \delta 160.5$ $(q ; J=37.8 \mathrm{~Hz}), 155.1,139.9,124.6,119.9,101.2,44.4$, $42.7,38.5,33.1,30.9,29.1,24.0,14.6$.

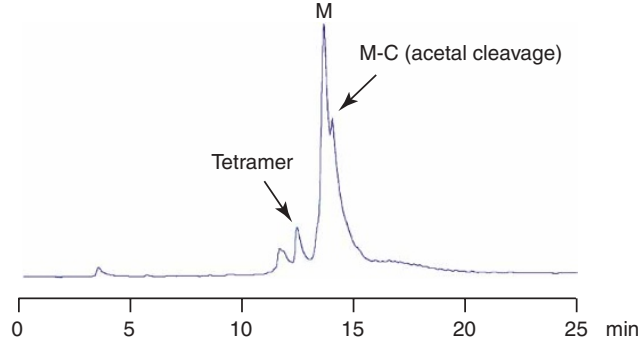

Figure 8 | Typical HPLC profile of the crude reaction mixture after imine reduction and boramine hydrolysis. The elution order is reduced tetrameric nanocontainer $\mathbf{8}$, hexameric nanocontainer $\mathbf{4}(\mathrm{M})$ and nanocontainer $\mathbf{4}$ lacking one acetal group (M-C). (Conditions: column, Vydac RP-18, $5 \mu \mathrm{m}, 300 \AA$, $4.6 \times 250 \mathrm{~mm}$; mobile phase, $\mathrm{CH}_{3} \mathrm{OH} / \mathrm{H}_{2} \mathrm{O} / \mathrm{TFA}$ gradient 85:15:0.1 to 98:2:0.1

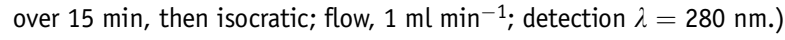


ESI-MS $\left(\mathrm{CH}_{3} \mathrm{OH} / \mathrm{H}_{2} \mathrm{O} / \mathrm{TFA}(98 / 2 / 0.1)(\mathrm{m} / \mathrm{z}) 1,478.9\left([\mathrm{M}+4 \mathrm{H}]^{4+}\right) ; 1,507.3\left([\mathrm{M}+4 \mathrm{H}+\mathrm{TFA}]^{4+}\right) ; 1,535.5\left([\mathrm{M}+4 \mathrm{H}+2 \mathrm{TFA}]^{4+}\right) ; 1,564.1\right.$ $\left([\mathrm{M}+4 \mathrm{H}+3 \mathrm{TFA}]^{4+}\right) ; 1,592.5\left([\mathrm{M}+4 \mathrm{H}+4 \mathrm{TFA}]^{4+}\right) ; 1,620.7\left([\mathrm{M}+4 \mathrm{H}+5 \mathrm{TFA}]^{4+}\right) ; 1,649.1\left([\mathrm{M}+4 \mathrm{H}+6 \mathrm{TFA}]^{4+}\right) ; 1,677.4\left([\mathrm{M}+4 \mathrm{H}+7 \mathrm{TFA}]^{4+}\right)$; $1,706.0\left(\left[\mathrm{M}+4 \mathrm{H}+8 \mathrm{TFA}^{4+}\right)^{4}\right)$ MALDI-TOF MS $(\mathrm{m} / \mathrm{z}) 5912.28\left([\mathrm{M}+\mathrm{H}]^{+}, 100 \%\right)$.

ACKNOWLEDGMENTS We thank the National Science Foundation for support of this research (Grants CHE-0431749 and CHE-0518351).

COMPETING INTERESTS STATEMENT The authors declare no competing financial interests.

Published online at http://www.natureprotocols.com

Rights and permissions information is available online at http://npg.nature.com/ reprintsandpermissions

1. Cram, D.J. \& Cram, J M. Container Molecules and their Guests. (Royal Society of Chemistry, Cambridge, 1994).

2. Jasat, A. \& Sherman, J.C. Carceplexes and hemicarceplexes. Chem. Rev. 99, 931-967 (1999).

3. Warmuth, R. \& Yoon, J. Recent highlights in hemicarcerand chemistry. Acc. Chem Res. 34, 95-105 (2001).

4. Warmuth, R. The inner phase of molecular container compounds as a novel reaction environment. J. Incl. Phenom. 37, 1-38 (2000).

5. Lützen, A. Self-assembled molecular capsules-even more than nano-sized reaction vessels. Angew. Chem. Int. Ed. 44, 1000-1002 (2005).

6. Cram, D.J., Tanner, M.E. \& Thomas, R. The taming of cyclobutadiene. Angew. Chem. Int. Ed. Engl. 30, 1024-1027 (1991).

7. Warmuth, R. o-Benzyne: strained alkyne or a cumulene? NMR characterization in a molecular container. Angew. Chem. Int. Ed. 36, 1347-1350 (1997).

8. Liu, X., Chu, G., Moss, R.A., Sauers, R.R. \& Warmuth, R. Fluorophenoxycarbene inside a hemicarcerand: a bottled singlet carbene. Angew. Chem. Int. Ed. 44, 1994-1997 (2005).

9. Yoshizawa, M., Kusukawa, T., Fujita, M. \& Yamaguchi, K. Ship-in-a-bottle synthesis of otherwise labile cyclic trimers of siloxanes in a self-assembled coordination cage. J. Am. Chem. Soc. 122, 6311-6312 (2000).

10. Kang, J. \& Rebek, J., Jr. Acceleration of a Diels-Alder reaction by a self-assembled molecular capsule. Nature 385, 50-52 (1997).

11. Fiedler, D., Bergman, R.G. \& Raymond, K.N. Supramolecular catalysis of a unimolecular transformation: aza-cope rearrangement within a self-assembled host. Angew. Chem. Int. Ed. 43, 6748-6751 (2004).

12. Yoshizawa, M., Takeyama, Y., Kusukawa, T. \& Fujita, M. Cavity-directed, highly stereoselective [2+2] photodimerization of olefins within self-assembled coordination cages. Angew. Chem. Int. Ed. 41, 1347-1349 (2002).

13. Warmuth, R., Maverick, E.F., Knobler, C.B. \& Cram, D.J. Through-shell alkyl lithium additions and borane reductions. J. Org. Chem. 68, 2077-2088 (2003).

14. Yoshizawa, M., Tamura, M. \& Fujita, M. Diels-Alder in aqueous molecular hosts: unusual regioselectivity and efficient catalysis. Science 312, 251-254 (2006).

15. Pagba, C. et al. Hybrid photoactive assemblies: electron injection from host-guest complexes into semiconductor nanoparticles. J. Am. Chem. Soc. 126, 9888-9889 (2004).

16. Menozzi, E. et al. Surface-confined single molecules: assembly and disassembly of nanosize coordination cages on gold (111). Chem. Eur. J. 10, 2199-2206 (2004).
17. Gibb, C.L.D. \& Gibb, B.C. Well-defined, organic nanoenvironments in water: the hydrophobic effect drives a capsular assembly. J. Am. Chem. Soc. 126, 11408-11409 (2004)

18. Mough, S.T., Goeltz, J.C. \& Holman, K.T. Isolation and structure of an "imploded" cryptophane. Angew. Chem. Int. Ed. 43, 5631-5635 (2004).

19. Rebek, J., Jr. Assembly and encapsulation with self-complementary molecules. Chem. Soc. Rev. 25, 255-264 (1996).

20. Mateos-Timoneda, M.A., Crego-Calama, M. \& Reinhoudt, D.N. Supramolecular chirality of self-assembled systems in solution. Chem. Soc. Rev. 33, 363-372 (2004).

21. MacGillivray, L.R. \& Atwood, J.L. Structural classification and general principles for the design of spherical molecular hosts. Angew. Chem. Int. Ed. 38, 1018-1033 (1999).

22. Fujita, M., Tominaga, M., Hori, A. \& Therrien, B. Coordination assemblies from a Pd(II)-cornered square complex. Acc. Chem. Res. 38, 371-380 (2005).

23. Seidel, S.R. \& Stang, P.J. High-symmetry coordination cages via self-assembly. Acc. Chem. Res. 35, 972-983 (2002).

24. Olenyuk, B., Whiteford, J.A., Fechtenkoetter, A. \& Stang, P.J. Self-assembly of nanoscale cuboctahedra by coordination chemistry. Nature 398, 796-799 (1999).

25. Tominaga, M. et al. spherical coordination networks that self-organize from 36 small components. Angew. Chem. Int. Ed. 43, 5621-5625 (2004).

26. Liu, X., Liu, Y., Li, G. \& Warmuth, R. One-pot 18 component synthesis of an octahedral nanocontainer molecule. Angew. Chem. Int. Ed. 45, 901-904 (2006).

27. Barrett, E.S., Irwin, J.L., Edwards, A.J. \& Sherburn, M.S. Superbowl container molecules. J. Am. Chem. Soc. 126, 16747-16749 (2004).

28. Makeiff, D.A. \& Sherman, J.C. A six-bowl carceplex that entraps seven guest molecules. J. Am. Chem. Soc. 127, 12363-12367 (2005).

29. Rowan, S.J., Cantrill, S.J., Cousins, G.R.L., Sanders, J.K.M. \& Stoddart, J.F. Dynamic covalent chemistry. Angew. Chem. Int. Ed. 41, 898-952 (2002).

30. Lehn, J.-M. Dynamic combinatorial chemistry and virtual combinatorial libraries. Chem. Eur. J. 5, 2455-2463 (1999).

31. Tunstad, L.M. et al. Host-guest complexation. 48. 0ctol building blocks for cavitands and carcerands. J. Org. Chem. 54, 1305-1312 (1989).

32. Bryant, J.A., Blanda, M.T., Vincenti, M. \& Cram, D.J. Host-guest complexation. 55. Guest capture during shell closure. J. Am. Chem. Soc. 113, 2167-2172 (1991)

33. Quan, M.L.C. \& Cram, D.J. Constrictive binding of large guests by a hemicarcerand containing four portals. J. Am. Chem. Soc. 113, 2754-2755 (1991).

34. Mendoza, S., Davidov, P.D. \& Kaifer, A.E. Electrochemistry of encapsulated guests: ferrocene inside Cram's hemicarcerands. Chem. Eur. J. 4, 864-870 (1998).

35. Liu, X. \& Warmuth, R. Solvent effects in thermodynamically controlled multicomponent nanocapsule syntheses. J. Am. Chem. Soc. 128, 14120-14127 (2006).

36. Gilman, H. \& Cartledge, F.K. The analysis of organolithium compounds. J. Organomet. Chem. 2, 447-454 (1964).

37. Suffert, J. Simple direct titration of organolithium reagents using $\mathrm{N}$-pivaloyl-otoluidine and/or N-pivaloyl-o-benzylaniline. J. Org. Chem. 54, 509-510 (1989). 